\title{
Production and quality of Urochloa decumbens (stapf) r.d.webster forage co-related to the physical and chemical properties of the soil
}

\author{
Flávio Carlos Dalchiavon ${ }^{1 *}$, Rafael Montanari ${ }^{2}$, Marcelo Andreotti $^{2}$
}

10.1590/0034-737X201764030013

\begin{abstract}
Frequently degraded pastureland characterized by low soil fertility and compacted surface is the basic environment of Brazilian livestock. The physical and chemical characterization of soil and its co-relationship with forage production are determining factors for performance of animals raised on pasture. The objective was to analyze the forage production of Urochloa decumbens grass correlated, linearly and spatially, with physical and chemical attributes of a savannah soil in Selvíria - MS, Brazil. A geostatistical web was introduced for the collection of soil and plant data, with 120 sampling sites within an area of 56.09 ha. The descriptive analysis of the data was undertaken and linear co-relationships, both simple and multiple, were established between plant and soil properties. Semivariograms were modeled and their respective krigings and cross-validations obtained, coupled to co-krigings (plant and soil). Production of dry matter and crude protein rates of $U$. decumbens may be estimated by regressions and the mechanical resistance to penetration and gravimetric humidity of the soil evaluated. Since organic matter rate and the gravimetric humidity of the soil are corelated spatially with the rate of crude protein of $U$. decumbens, they are the best factors to calculate or increase the forage crude protein rate.
\end{abstract}

Key words: geoestatistics; precision agriculture; soil management and conservation; spatial variability.

\section{RESUMO}

\section{Produção e qualidade de forragem de Urochloa decumbens (stapf) r.d.webster correlacionada com atributos físico-químicos do solo}

A pecuária brasileira está fundamentada em pastagens, muitas vezes degradadas, e que tem como indicativos desta degradação, a queda de fertilidade do solo e a compactação superficial do solo. Portanto, a caracterização físico-química do solo e a sua correlação com a produção de forragem são determinantes para o desempenho animal em pasto. No ano de 2009, no município de Selvíria - MS, Brasil, em condições de Cerrado, objetivou-se analisar os atributos produtivos de Urochloa decumbens correlacionado-os, linear e espacialmente, com atributos físico e químicos de um solo de Cerrado. Foi instalada uma malha geoestatística para a coleta de dados do solo e da planta, com 120 pontos amostrais, numa área de 56,09 ha. Realizou-se a análise descritiva dos dados, estabelecendo-se correlações lineares, simples e múltiplas, entre os atributos da planta e os do solo. Foram modelados semivariogramas, obtendo-se as respectivas krigagens e validações cruzadas. Também foram estabelecidas as cokrigagens de interesse (planta $x$ solo). Tanto a produção de matéria seca quanto os teores de proteína bruta de $U$. decumbens podem ser estimados por meio de regressões, avaliando a resistência mecânica à penetração e umidade gravimétrica do solo. Os teores de matéria orgânica e a umidade gravimétrica do solo correlacionam-se espacialmente com os teores de proteína bruta da $U$. decumbens, demonstrando serem os melhores atributos para estimar ou aumentar o teores de proteína bruta da forragem.

Palavras-chave: geoestatística; agricultura de precisão; manejo e conservação do solo; variabilidade espacial.

Submetido em 27/12/2014 e aprovado em 16/05/2017

${ }^{1}$ Instituto Federal de Educação, Ciência e Tecnologia de Mato Grosso, Campo Novo do Parecis, Mato Grosso, Brasil. flavio.dalchiavon@cnp.ifmt.edu.br

${ }^{2}$ Universidade Estadual Paulista "Júlio de Mesquita Filho", Faculdade de Engenharia de Ilha Solteira, Departamento de Fitossanidade, Engenharia Rural e Solos, Ilha Solteira, São Paulo, Brasil. montanari@agr.feis.unesp.br; dreotti@agr.feis.unesp.br

*Autor para correspondência: flavio.dalchiavon@cnp.ifmt.edu.br 


\section{INTRODUCTION}

Brazil has the most numerous commercial cattle herd in the world and the state of Mato Grosso do Sul contributes largely for such ranking. Although the country is known to have large areas for extensive planting of forages (Ribeiro-Júnior et al., 2017), low productivity and unsatisfactory scientific indexes are verified when compared with rates from other countries which also export beef worldwide (Cavallini et al., 2010; Pariz et al., 2011; Montanari et al., 2013a). In spite of low productivity rates, the Brazilian commercial cattle herd amounts to 209,541,109 units. It has been estimated that $89 \%$ are raised exclusively on pasture in native or cultivated pasturelands covering some 172 million ha and approximately $85 \%$ of this area is pasture of the genus Urochloa (Leal et al., 2016).

Factors such as species, climate (water, light, and temperature), fertility and physical texture of soil, forage cycle, harvest management, animal monitoring, and others may affect the chemical composition and thus the availability of food energy (Leonel et al., 2009; Lisbôa et al., 2016). The production of dry matter and satisfactory rates of crude protein and acceptability by the animals are important factors in the selection of a cultivar for pasture sowing (Maranhão et al., 2009).

According to Cavallini et al. (2010) and Montanari et al. (2010), studies on the spatial variability of the soil physical and chemical properties are highly relevant in agriculture and livestock-raising since they determine specific regions for management. The use of semivariograms at this phase helps in planning soil sample collection to analyze the spatial variability of the most interesting properties by geostatistical techniques that would help the farmer in determining and improving the productive, physical, and chemical capacity of the soil.

In fact, Pariz et al. (2011) investigated the spatial variability of forage productivity and the physical properties of soil planted with $U$. decumbens pasture in the Brazilian savannah and discovered that the geostatistical use could be underscored as an important tool to understand the interactions in a pasture ecosystem, reduce possible causes of degradation, and demonstrate the best alternative management for the soil-plant-animal complex. In an analogous way, Montanari et al. (2013b) evaluated the production of dry matter of $U$. decumbens according to the chemical attributes of a Latosol in Selvíria, MS, Brazil and verified that the organic matter content was a good index of soil quality when co-related to the productivity of Urochloa grass. Further, the rate of crude protein was also a good quality index of the forage plant with regard to the production of dry matter.

Taking into account the Brazilian relevance in livestock, the current paper evaluated the forage production of $U$. decumbens grass correlated, linearly and spatially, with physical-chemical attributes of a savannah soil.

\section{MATERIAL AND METHODS}

The experiment was performed In the Teaching, Research and Extension Farm (FEPE) in Selvíria, MS, Brazil, of the Engineering Faculty of the Universidade Estadual Paulista(UNESP), 51 ${ }^{\circ} 24^{\prime} 46^{\prime \prime}$ W and 20²1'44'" S (Figure 1); mean altitude $342 \mathrm{~m}$. The soil in the area is a typical mediumtexture Red-Yellow Latosol (Oxisol), a moderate, hypodystrophic, alic, caulinitic, hypoferric, very deep, moderately acid, with $410 \mathrm{~g} \mathrm{~kg}^{-1}$ of sand, $70 \mathrm{~g} \mathrm{~kg}^{-1}$ of silt, and $520 \mathrm{~g} \mathrm{~kg}^{-1}$ of clay at $0-0.20 \mathrm{~m}$ depth. The initial chemical attributes of the soil, assessed respectively at the depths of 0.0-0.10 and 0.10-0.20 m, were: $\mathrm{pH}(\mathrm{CaCl} 2)=4.9$ and 4.7; $\mathrm{H}+\mathrm{Al}=26$ and $22 \mathrm{mmol}_{\mathrm{c}} \mathrm{dm}^{3} ; \mathrm{P}($ resin $)=10$ and $5 \mathrm{mg} \mathrm{dm}^{3}$; $\mathrm{K}^{+}=0.6$ and $0.1 ; \mathrm{Ca}^{2+}=9$ and $7 ; \mathrm{Mg}^{2+}=4$ and $3 \mathrm{mmol}_{\mathrm{c}} \mathrm{dm}^{3}$; and $\mathrm{V}=34$ and $31 \%$. The Urochloa decumbens pasture was implemented in 1978 and has been managed under continuous stocking (mean stocking rate of 1.5 UA in that period) for Guzerá cattle raising, receiving liming and fertilization during implementation and rehabilitation in 1988. It is currently in a stage of moderate degradation, with losses in productivity and quality, broadleaf weeds, and soil compaction.

According to Köppen, climate is Aw, featuring megathermal humid climate, with dry winters and hot rainy summers. Mean annual rainfall is approximately $1232 \mathrm{~mm}$; mean annual temperature is close to $24.5{ }^{\circ} \mathrm{C}$ and relative humidity between 70 and $80 \%$.

Urochloa decumbens (cultivar Basilisk) was planted about 25 years ago and has been extensively employed, with liming when required, to upgrade base saturation at $60 \%$. For data collection in March 2009, U. decumbens was in its tenth reformation year with surface scarification and liming.

Directions $\mathrm{x}$ and $\mathrm{y}$ of the cartesian coordinate system were defined in the allocation of the experimental design, with 120 sampling sites distributed in 56.09 ha $(1060.23 \times$ $529.00 \mathrm{~m}$ ). Spacing of sites varied between 35.18 and 279.93 $\mathrm{m}$. Soil and plant properties, individually collected around each sampling site of the experimental design were analyzed. Soil properties comprised mechanical resistance to penetration (RP) and gravimetric humidity $(\mathrm{GH})$ at layers 0-0.10 m (RP1 and GH1); 0.10-0.20 m (RP2 and GH2); 0.20$0.30 \mathrm{~m}$ (RP3 and GH3); 0.30-0.40 m (RP4 and GH4); 0.40$0.50 \mathrm{~m}$ (RP5 and GH5); and 0.50-0.60 m (RP6 and GH6). Resistance to penetration was evaluated once by impact penetration meter at each site and calculated according to the following expression (Dalchiavon et al., 2011):

$$
R P=\left\{5.581+8.891 \times\left[\frac{N}{(P-A) \times 10}\right]\right\} \times 0.0981
$$


in which RP is the soil mechanical resistance to penetration $(\mathrm{MPa}) ; \mathrm{N}$ is the number of impacts by the penetration-meter hammer for reading; and $\mathrm{A}$ and $\mathrm{P}$ are, respectively, penetration readings in the soil before and after impacts (cm). Deformed samples of soil were collected by shovel drill, with $0.10 \mathrm{~m}$ diameter and $0.20 \mathrm{~m}$ height, to determine $\mathrm{GH}\left(\mathrm{kg} \mathrm{kg}^{-1}\right)$. The hydrogenionic potential ( $\mathrm{pH}$ $\mathrm{CaCl}_{2}$ ) of the soil and organic matter (OM) rates by organic carbon were determined from the same samples. The latter was obtained by the humid combustion method through calorimetry, by the following formula:

$O M=C \times 1,724 \times 10$

in which $\mathrm{OM}$ is the rate of organic matter $\left(\mathrm{g} \mathrm{dm}^{-3}\right)$ and $\mathrm{C}$ is the rate of organic carbon. Soil samples were analyzed in the Physics and Soil Fertility Laboratories of the Universidade Estadual Paulista, Ilha Solteira, SP, Brazil.

Plant factors comprised production of forage green matter (GM); production of forage dry matter (DM); rate of crude protein (CP); neutral detergent fiber rate (NDF); total digestible nutrient rates (TDN); and ash rates (ASH), collected above pasture height $(0.20 \mathrm{~m})$. Samples for the evaluation of the production of green matter of the Urochloa grass were collected by a $2 \times 2 \mathrm{~m}$ metal square. The material within the square was harvested at approximately 0.20 $\mathrm{m}$ from the ground. A sample was then retrieved from the material, conditioned in a paper package, weighted and placed in a forced-air buffer at $55^{\circ} \mathrm{C}$ for $72 \mathrm{~h}$. The production of the forage dry matter was determined. Neutral detergent fiber and TDN rates were determined according to methodology by Werner et al. (1997), whereas rates of crude protein and ashes were determined following Silva \& Queiróz (2002).

Classical description analysis was performed for each factor under analysis by SAS (Statistical Analysis System, version 8.2.), in which mean, median, minimum and maximum rates, standard deviation, coefficient of variance, kurtosis, asymmetry, and distribution of frequency were calculated. Co-relation matrix was prepared to determine the simple linear co-relationships for combination, two by two, between the factors under analysis. The modeling of simple linear regressions was henceforth performed on Excel sheets. On the other hand, multiple linear regression of the dependent variables (plant factors) was performed by computer package of SAS ("stepwise") at 10\% probability for the inclusion and exclusion of the variables in the model and compared to the independent variables (plants or soil factors). Consequently, those that provided the best equation to estimate the respective dependent variable would be selected.

Geostatistical analysis was undertaken by Gamma Design Software 7.0, following procedures by Dalchiavon and Carvalho (2012). Spatial dependence was analyzed for each factor by calculating the semivariograms, in which adjustments were performed in the first place by the initial selection of the lowest sum of the squares of the deviants (SSD); the highest coefficient of determination $\left(\mathrm{r}^{2}\right)$; and the highest evaluator of spatial dependence (ESD). Interpretation of ESD also followed method by Dalchiavon and Carvalho (2012): ESD <20\% = spatial variable with very low dependence (VL); $20 \%$ d" ESD < 40\% = low dependence $(\mathrm{L}) ; 40 \%$ d" $\mathrm{ESD}<60 \%$ = fair dependence $(\mathrm{F})$; $60 \%$ d" ESD < $80 \%=$ high dependence $(\mathrm{H})$; and $80 \%$ d" $\mathrm{ESD}<100 \%=$ very high dependence $(\mathrm{VH})$.

Co-krigings between plant factors and between the later and soil factors were performed.

\section{RESULTS AND DISCUSSION}

The descriptive analysis of the plant data and the soil chemical properties showed low variability for NDF, TDN, $\mathrm{pH} 1$, and $\mathrm{pH} 2$; medium for $\mathrm{ASH}$; high for $\mathrm{CP}, \mathrm{OM} 1$, and $\mathrm{OM}$; ; and very high for GM and DM (Table 1). As a rule, data were highly similar to those reported by Dalchiavon et al. (2013a) and Montanari et al. (2013b,c) when they investigated the variability of the chemical factors of soils cultivated with rice, Urochloa, and beans, respectively. The soil physical factors were medium (RP4 to RP6, UG1 to UG6) and high (RP1 to RP3) data variability has been registered (Table 2). High variability for RP data up to 0.30 $\mathrm{m}$ is mainly due to management of reform and incorporation of corrective measures in the pasture and to the effect of

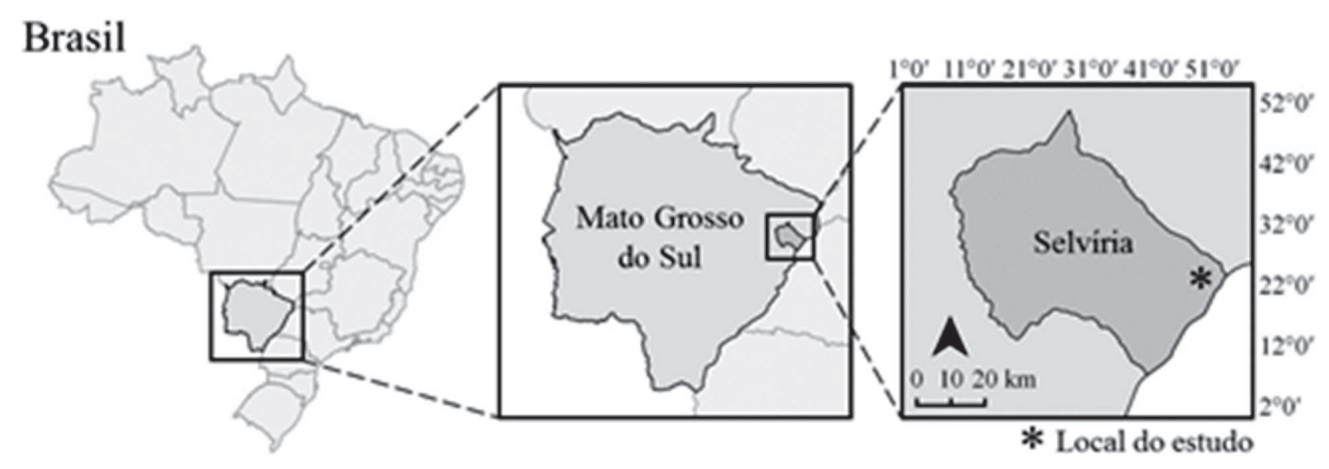

Figure 1: Place of study implementation in a Brazilian savannah (Selvíria, MS, Brazil, 2009). 


\begin{tabular}{|c|c|c|c|c|c|c|c|c|c|c|}
\hline \multirow{3}{*}{$\begin{array}{l}\text { Probability of } \\
\text { Attribute }\end{array}$} & \multicolumn{10}{|c|}{ Descriptive statistical measures } \\
\hline & \multirow{2}{*}{ Mean } & \multirow{2}{*}{ Median } & \multicolumn{2}{|c|}{ Rate } & \multirow{2}{*}{$\begin{array}{l}\text { Standard } \\
\text { deviation }\end{array}$} & \multicolumn{3}{|c|}{ Coefficient } & \multicolumn{2}{|c|}{ Probability of test (b) } \\
\hline & & & Minimum & Maximum & & Variation $(\%)$ & Kurtosis & Asymmetry & $\operatorname{Pr}<w$ & FD \\
\hline GM $\left(\mathrm{t} \mathrm{ha}^{-1}\right)$ & 5.39 & 5.012 & 0.428 & 14.992 & 3.014 & 55.9 & 1.161 & 1.002 & $10^{-4}$ & ND \\
\hline $\mathrm{DM}\left(\mathrm{t} \mathrm{ha}^{-1}\right)$ & 1.50 & 1.372 & 0.140 & 4.172 & 0.895 & 59.7 & 1.734 & 1.354 & $10^{-4}$ & ND \\
\hline $\mathrm{CP}(\%)$ & 7.59 & 7.67 & 2.94 & 12.56 & 15.9 & 21.0 & 0.382 & 0.264 & 0.643 & NO \\
\hline $\operatorname{NDF}(\%)$ & 67.18 & 67.20 & 56.78 & 76.11 & 36.6 & 5.5 & -0.226 & -0.073 & 0.911 & NO \\
\hline $\operatorname{TDN}(\%)$ & 55.75 & 55.76 & 52.05 & 60.11 & 15.3 & 2.7 & -0.244 & 0.114 & 0.857 & NO \\
\hline Ash (\%) & 7.96 & 7.92 & 5.30 & 11.80 & 11.7 & 14.7 & 0.395 & 0.454 & 0.220 & NO \\
\hline pH1 & 5.0 & 5.0 & 4.1 & 5.9 & 0.3 & 6.2 & 0.344 & 0.029 & 0.212 & NO \\
\hline $\mathrm{pH} 2$ & 4.8 & 4.8 & 4.2 & 5.8 & 0.4 & 7.4 & 0.514 & 0.467 & $8.10^{-4}$ & ND \\
\hline OM1 $\left(\mathrm{g} \mathrm{dm}^{-3}\right)$ & 12.6 & 12.0 & 7.0 & 22.0 & 3.8 & 29.9 & “0.679 & 0.479 & $10^{-4}$ & ND \\
\hline $\mathrm{OM} 2\left(\mathrm{~g} \mathrm{dm}^{-3}\right)$ & 13.7 & 13.0 & 11.0 & 22.0 & 3.3 & 24.3 & “0.280 & 0.564 & $10^{-4}$ & ND \\
\hline \multicolumn{11}{|c|}{$\begin{array}{l}\text { GM - green matter; DM - dry matter; CP - crude protein; NDF - neutral detergent fiber; TDN - total digestible nutrients; pH1 - hydrogenionic potential 1; pH2 - hydrogenionic potential 2; OM1 - organic } \\
\text { matter 1; OM2 - organic matter 2; FD - frequency distribution; ND - non-determined; NO - normal. }\end{array}$} \\
\hline \multirow{3}{*}{$\begin{array}{l}\text { Probability of } \\
\text { Attribute }\end{array}$} & \multicolumn{10}{|c|}{ Descriptive statistical measures } \\
\hline & \multirow{2}{*}{ Mean } & \multirow{2}{*}{ Median } & \multicolumn{2}{|c|}{ Rate } & \multirow{2}{*}{$\begin{array}{l}\text { Standard } \\
\text { deviation }\end{array}$} & \multicolumn{3}{|c|}{ Coefficient } & \multicolumn{2}{|c|}{ Probability of test (b) } \\
\hline & & & Minimum & Maximum & & Variation $(\%)$ & Kurtosis & Asymmetry & $\operatorname{Pr}<w$ & FD \\
\hline RP1 (MPa) & 1.505 & 1.459 & 0.873 & 2.576 & 0.371 & 24.6 & -0.562 & 0.045 & 0.174 & $\mathrm{LN}$ \\
\hline RP2 (MPa) & 2.121 & 2.076 & 1.001 & 3.365 & 0.436 & 20.6 & 0.800 & 0.294 & 0.050 & NO \\
\hline RP3 (MPa) & 2.018 & 1.971 & 1.014 & 3.284 & 0.408 & 20.2 & 0.779 & 0.486 & 0.051 & NO \\
\hline RP4 (MPa) & 1.795 & 1.820 & 1.014 & 2.412 & 0.238 & 13.2 & 0.873 & -0.453 & 0.102 & NO \\
\hline RP5 (MPa) & 1.731 & 1.713 & 1.048 & 2.605 & 0.274 & 15.9 & 0.301 & 0.191 & 0.874 & NO \\
\hline RP6 (MPa) & 1.753 & 1.755 & 1.048 & 2.605 & 0.291 & 16.6 & -0.201 & 0.099 & 0.931 & NO \\
\hline GH1 $\left(\mathrm{kg} \mathrm{kg}^{-1}\right)$ & 0.108 & 0.106 & 0.037 & 0.159 & 0.019 & 17.9 & 0.811 & -0.025 & 0.105 & NO \\
\hline $\mathrm{GH} 2\left(\mathrm{~kg} \mathrm{~kg}^{-1}\right)$ & 0.101 & 0.101 & 0.061 & 0.150 & 0.016 & 16.2 & 0.054 & 0.301 & 0.686 & NO \\
\hline GH3 $\left(\mathrm{kg} \mathrm{kg}^{-1}\right)$ & 0.099 & 0.101 & 0.054 & 0.142 & 0.015 & 15.2 & 0.607 & 0.155 & 0.942 & NO \\
\hline GH4 $\left(\mathrm{kg} \mathrm{kg}^{-1}\right)$ & 0.100 & 0.100 & 0.057 & 0.137 & 0.015 & 15.1 & 0.336 & 0.058 & 0.292 & NO \\
\hline GH5 $\left(\mathrm{kg} \mathrm{kg}^{-1}\right)$ & 0.103 & 0.104 & 0.080 & 0.132 & 0.012 & 12.0 & -0.648 & 0.065 & 0.050 & NO \\
\hline GH6 $\left(\mathrm{kg} \mathrm{kg}^{-1}\right)$ & 0.106 & 0.106 & 0.063 & 0.138 & 0.014 & 12.9 & -0.198 & “0.132 & 0.223 & NO \\
\hline
\end{tabular}

RP1, RP2, RP3, RP4, RP5, and RP6 - soil resistance to penetration; GH1,GH2, GH3, GH4, GH5, and GH6 - soil gravimetric humidity, in depthFD - frequency distribution; ND - non-determined; NO - normal. 
trampling by animals on these layers. The above indicates the soil heterogeneity evaluated by the high coefficients of variations and with the consequent interference in the forage production of the region. Souza et al. (2006), Dalchiavon et al. (2011), and Montanari et al. (2013a) also investigated the variability of the physical properties in managed soils with sugarcane, soybean, and Urochloa in their respective geostatistical studies and reported coefficients of variation similar to those of the current analysis.

With the exception of GM, DM, pH2, OM1, and OM2, which had a non-determined frequency distribution, and RP1 with log normal frequency distribution, all the other factors provided a normal frequency distribution (Tables 1 and 2). Probability varied between 0.050 (RP2) and 0.664 (UG3) and showed that centrally trend measures did not represent atypical rates in the distribution, which is typical of plant data, as underscored by Dalchiavon et al. (2013b).

Green matter (GM) and DM productivity were 5.39 and $1.50 \mathrm{t} \mathrm{ha}^{-1}$, respectively (Table 1). Dry matter rate was actually low when compared with productivity reported by Montanari et al. (2013b,a). Low DM productivity was high due to the fact that the area was a continuous pasture at that moment, with more than 10 years after reformation and without any fertilization, with only one animal unit per hectare. In fact, it simulated the normal conditions used by the farmers in the reagion. However, there was a great decrease in mean annual productivity of $U$. decumbens in low fertility soils and rates between 1 and $2 \mathrm{tha}^{-1}$ of DM were normal (Serrão and Simão Neto, 1971). In fact, tropical forages provide dry matter according to clear-cut seasonality, or rather, between the rainy and dry seasons, and thus determine the lack of uniformity in the distribution of production throughout the year (Evangelista et al., 2004; Crusciol et al., 2012; Pariz et al., 2017).

The 7.59 percentage of CP in the DM (Table 1) showed that it was $15 \%$ higher than the rate reported by Montanari et al. (2013b), when these authors studied the same forage species in a Latosol in Selvíria, MS, Brazil. According to Milford and Minson (1966), CP rate in DM is adequate since only rates lower than $7 \%$ of DP in the forage actually show any reduction in the intake of DM by the animals. In fact, it reduces the digestibility of DM caused by nitrogen deficiency to the ruminal bacteria.

Means of NDF, TDN, and ASH were 67.18\%, 55.75\%, and $7.96 \%$, respectively. It should be emphasized that the higher the ADF, the less is the digestibility. On the other hand, NDF has a negative co-relationship with forage intake, with $40 \%$ of $\mathrm{ADF}$ and $60 \%$ of NDF as the respective limits of digestibility and intake. As a rule, TDN rates were over 55\%, which was considered the best by Van Soest (1994) in tropical forages.
In the case of the soil chemical properties, $\mathrm{pH}$ provided high acidity ( $\mathrm{pH}$ between 4.4 and 5.0) with low $\mathrm{OM}$ availability, following classification by Raij et al. (1997). In fact, these rates were lower than $15 \mathrm{~g} \mathrm{dm}^{-3}$ (Table 1) and partially explained the low production of the forage DM.

It should be highlighted that RP provided the lowest rates, considered medium $(1.0 \leq \mathrm{RP}<2.0 \mathrm{MPa})$ by Arshad et al. (1996), up to 0.10-m depth and between 0.30 and 0.60 $\mathrm{m}$ (Table 2). However, RP rates were considered high $(2.0 \leq$ $\mathrm{RP}<4.0 \mathrm{MPa}$ ) between 0.10 and $0.30 \mathrm{~m}$, since rates above 2.0 MPa in most cultures start showing limitations to the normal development of the root system (Tormena et al., 1998). The above rates clearly show the effects of natural thickening of the neighboring layers and the effects of animal trampling of the upper layers. The phenomenon mainly depends on soil class, humidity rate, animal density rates, mass of forage produced (deficient soil covering), and the forage species in the system (Marchão et al., 2007).

It is not only important to underscore RP rates but also the soil humidity conditions (GH) from which the data were obtained, since these qualities are normally inversely proportional (Dalchiavon et al., 2011). It must be emphasized that, at the instance soil data collection was done, $\mathrm{GH}$ was between 0.099 (UG3) and $0.108 \mathrm{~kg} \mathrm{~kg}^{-1}$ (UG1) (Table 2). Montanari et al. (2013a) researched the corelationship of forage production with the physical properties of an Argisol in Aquidauana, MS, Brazil and reported $4.761 \mathrm{MPa}(\mathrm{RP})$ and $0.088 \mathrm{~kg} \mathrm{~kg}^{-1}(\mathrm{GH})$ for the 0 $0.20 \mathrm{~m}$ layer. Above data were highly critical than those in current research. On the other hand, Pariz et al. (2011) studied the spatial variability of forage productivity and the physical properties of soil with $U$. decumbens pasture in the Brazilian savannah and registered $3.177 \mathrm{MPa}(\mathrm{RP})$ and $0.140 \mathrm{~kg} \mathrm{~kg}^{-1}(\mathrm{GH})$, also at the $0-0.20 \mathrm{~m}$ layer.

Studies on Pearson's linear co-relationships of DM and $\mathrm{CP}$ with the soil properties revealed the following, featuring relevant agronomy interest: DM had positive and significant co-relationships $(\mathrm{n}=120)$ with $\mathrm{GH} 3\left(\mathrm{r}=0.221^{*}\right)$, UG5 $(r=0.247 * *)$, and UG6 $(r=0.371 * *)$, agreeing with rates by Cavallini et al. (2010), who reported positive corelationship between DM and GH. Analogically, CP corelated negatively with RP3 $\left(\mathrm{r}=-0.192^{*}\right)$, UG1 $\left(\mathrm{r}=-0.183^{*}\right)$, UG2 $\left(r=-0.308^{* *}\right), \mathrm{UG} 3\left(\mathrm{r}=-0.313^{* *}\right), \mathrm{UG} 4\left(\mathrm{r}=-0.328^{* *}\right)$, UG5 $\left(\mathrm{r}=-0.317^{* *}\right)$, and UG6 $\left(\mathrm{r}=-0.330^{* *}\right)$. The analyses of such co-relationships demonstrated that the higher the humidity rate in the soil, the greater the production of dry matter by forage. In fact, an increase in hydric availability would ensue and, therefore, a probable improvement in the absorption of the soil nutrients, with better vegetal growth. However, the forage $\mathrm{CP}$ would be lower since the co-relationship between DM and CP was significantly high $\left(\mathrm{r}=\right.$ " $\left.0.331^{* *}\right)$, probably due to the effect of high $\mathrm{N}$ leaching from the mineralization of the soil OM. 
Potential (Equations 3 to 6) and linear (Equations 7 to 12) equations were modeled, which demonstrated a positive co-relationship between DM and GH, showing that increase in GH would have a positive effect on DM (Equations 3 to 5) due to a greater biomass production. Although tolerant to water deficits, $U$. decumbens still revealed seasonality in reproduction caused by drought or low temperatures.

On the other hand, inverse relationships occurred between $\mathrm{CP}$ and RP3 and between $\mathrm{CP}$ and GH (Equations 6 to 12), in which an increase in RP3 and in GH would have a negative effect on $\mathrm{CP}$ due to the physical restrictions imposed on root growth by direct compact (RP increase) or indirectly by soil drenching caused by compact, with an increase in GH. Therefore, the production of DM will be 1.27, 1.28, and 1.27 tha $^{-1}$ when GH3, GH5, and GH6 are, respectively, $0.099,0.103$ and $0.106 \mathrm{~kg} \mathrm{~kg}^{-1}$ (Equations 3 to 5; Table 2). According to the model, CP will be 9.91, 7.58, $7.58,7.59,7.57,7.58$, and $8.00 \%$ when RP3, GH1, GH2, GH3, GH4, GH5, and GH6 are, respectively, 2.018 MPA, 0.108, $0.101,0.099,0.100,0.103$, and $0.106 \mathrm{~kg} \mathrm{~kg}^{-1}$ (Equations 6 to 12; Table 2).

Model (Equation 13) for the analysis of multiple linear regression of $\mathrm{CP}$ due to the soil physical and chemical properties explains approximately $21.9 \%$ of $\mathrm{CP}$ variation rate of $U$. decumbens $\left(\mathrm{R}^{2}=0.219 * *\right)$. The coefficients of the independent variables RP4 and RP5 were significant at 1\%, whereas coefficients of $\mathrm{GH} 3$ and $\mathrm{GH} 6$ were significant at $5 \%$ probability. By means of the above regression and taking into account the mean rates of the independent factors (Table 2), CP rate of $7.60 \%$ may be estimated. Since this rate is close to the mean CP rate in current analysis (7.59\%), the exactness of Equation 13 and its agronomic importance in estimating the parameter are confirmed.

$$
\begin{array}{ll}
D M=10.75 \times G H 3^{0.922^{* *}} & \left(\mathrm{r}=0.237^{* *}\right) \\
D M=50.63 \times G H 5^{1.619^{* *}} & \left(\mathrm{r}=0.317^{* *}\right) \\
D M=85.46 \times G H 6^{1.874 * *} & \left(\mathrm{r}=0.400^{* *}\right) \\
C P=8.554 \times R P 3^{0.210^{*}} & \left(\mathrm{r}=-0.196^{*}\right) \\
C P=9.21-15.09^{*} \times G H 1 & \left(\mathrm{r}=-0.183^{*}\right) \\
C P=10.62-30.05^{* *} \times G H 2 & \left(\mathrm{r}=-0.308^{* *}\right) \\
C P=10.87-33.09^{* *} \times G H 3 & \left(\mathrm{r}=-0.313^{* *}\right) \\
C P=11.06-34.90^{* *} \times G H 4 & \left(\mathrm{r}=-0.328^{* *}\right) \\
C P=11.78-40.79 * * \times G H 5 & \left(\mathrm{r}=-0.317^{* *}\right) \\
C P=11.68-38,52 * * \times 6 H 6 & \left(\mathrm{r}=-0.330^{* *}\right) \\
C P=13.228-2,584 * * \times R P 4+2.164 * * \times R P 5-22,534 * \times \\
G H 3-23,601 * \times G H 6 \quad\left(\mathrm{r}^{2}=0.219^{* *}\right)
\end{array}
$$

Except for pH1, pH2, RP2, RP3, RP4, RP5, RP6, \#GH2, \#GH5, and \#GH6 with pure nugget effect, the other properties revealed spatial dependence and their distribution in space was not randomized (Tables 3 and 4). 
Table 4: Parameters of simple semivariograms adjusted for the mechanical resistance of the soil to penetration and gravimetric humidity of a dystrophic Red-Yellow Latosol of the Brazilian savannah (Selvíria, MS, Brazil, 2009)

\begin{tabular}{|c|c|c|c|c|c|c|c|c|c|c|c|}
\hline \multirow{3}{*}{ Attribute } & \multicolumn{11}{|c|}{ Adjustment parameters } \\
\hline & \multirow{2}{*}{ Model1 } & \multirow{2}{*}{ Co } & \multirow{2}{*}{$\mathrm{Co}+\mathrm{C}$} & \multirow{2}{*}{$\operatorname{Ao}(\mathbf{m})$} & \multirow{2}{*}{$\mathbf{r} 2$} & \multirow{2}{*}{ SSR } & \multicolumn{2}{|c|}{ SDE } & \multicolumn{3}{|c|}{ Cross-validation } \\
\hline & & & & & & & $\%$ & Class & $\mathbf{a}$ & b & $\mathbf{R}$ \\
\hline RP1 & sph (306) & $3.90 .10^{-3}$ & $9.28 .10^{-2}$ & 107.0 & 0.626 & $1.60 .10^{-4}$ & 95.8 & $\mathrm{VH}$ & 1.00 & 0.328 & 0.210 \\
\hline RP2 & pne & $1.90 .10^{-1}$ & $1.90 .10^{-1}$ & - & - & - & - & - & - & - & - \\
\hline RP3 & pne & $1.68 .10^{-1}$ & $1.68 .10^{-1}$ & - & - & - & - & - & - & - & - \\
\hline RP4 & pne & $5.81 .10^{-2}$ & $5.81 .10^{-2}$ & - & - & - & - & - & - & - & - \\
\hline RP5 & pne & $7.37 .10^{-2}$ & $7.37 .10^{-2}$ & - & - & - & - & - & - & - & - \\
\hline RP6 & pne & $8.48 .10^{-2}$ & $8.48 .10^{-2}$ & - & - & - & - & - & - & - & - \\
\hline \#GH1 & $\exp (379)$ & $5.40 .10^{-5}$ & $5.40 .10^{-5}$ & 183.0 & 0.361 & $1.37 .10^{-8}$ & 83.7 & $\mathrm{VH}$ & 0 & 0.928 & 0.390 \\
\hline \#GH2 & pne & $2.20 .10^{-4}$ & $2.20 .10^{-4}$ & - & - & - & - & - & - & - & - \\
\hline GH3 & sph (310) & $4.70 .10^{-5}$ & $2.58 .10^{-4}$ & 763.0 & 0.946 & $2.37 .10^{-9}$ & 82.0 & VH & 0 & 0.990 & 0.688 \\
\hline \#GH4 & sph (292) & $5.50 .10^{-5}$ & $1.11 .10^{-4}$ & 479.0 & 0.880 & $2.99 .10^{-10}$ & 50.4 & $\mathrm{MH}$ & 0 & 1.104 & 0.499 \\
\hline \#GH5 & pne & $9.20 .10^{-5}$ & $9.20 .10^{-5}$ & - & - & - & - & - & - & - & - \\
\hline \#GH6 & pne & $1.53 .10^{-4}$ & $1.53 .10^{-4}$ & - & - & - & - & - & - & - & - \\
\hline
\end{tabular}

RP - mechanical resistance to penetration; GH - gravimetric humidity, in depth; SSR - sum of the square of residues; SDE - spatial dependence evaluator,
${ }^{1}$ \#: attribute with data residue; parenthesis succeeding model: number of pairs in the first lag; ${ }^{(b)}$ sph: spheric, epp: pure nugget effect; exp: exponential.

즌 $\mathrm{GM}$ - green matter, DM - dry matter, CP - crude protein, FDN - neutral detergent fiber, TDN - total digestive nutrients; ASH - ashes, pH - hydrogenionic potential; OM - organic matter, in depth; SSR - sum of the square of residues; SDE - spatial dependence evaluator, with M - mean, VH - very high, H - high; L - low.

${ }_{0}^{1} \#=$ attribute with data residue; parenthesis succeeding model = number of pairs in the first lag; exp = exponential, gau = gaussian, sph = spheric; pne = pure nugget effect. 
The coefficient of spatial determination $\left(\mathrm{r}^{2}\right)$ of simple semivariograms lay between 0.361 (\#GH1) and 0.994 (OM2). It was the best semivariograph adjustment when analyzed by $\mathrm{r}^{2}$. Since the geostatistical extremes $\left(\mathrm{A}_{0}\right)$ lay between 107.0 (RP1) and $763.0 \mathrm{~m}(\mathrm{GH} 3)$, extreme rates for specific and localized managements that will be employed as reference in future research should not be lower than 107 $\mathrm{m}$, since they are the distance within which the rates of a specific quality are equal. For spatial dependence evaluation (SDE), classification varied between low (\#TDN; $\mathrm{SDE}=28.6 \%)$ and very high spatial dependence $(\mathrm{RP} 1$; $\mathrm{SDE}=95.8 \%$ ).

In the case of $\mathrm{CP}, \mathrm{OM} 1$ and $\mathrm{GH} 3$, or rather, the factors that provided co-krigings higher than $\mathrm{r}^{2}$ (Table 5), CP showed exponential model, $\mathrm{r}^{2}=0.981, \mathrm{~A}_{0}=180 \mathrm{~m}$, and very high SDE (86.3\%). In the case of OM1, spherical model, the parameters $\mathrm{r}^{2}, \mathrm{~A}_{0}$, and $\mathrm{SDE}$ were respectively $0.92,287.0$ $\mathrm{m}$, and $89.4 \%$, whereas, in the case of $\mathrm{GH} 3$, with spherical adjustment, they were $0.946,763.0 \mathrm{~m}$, and $82.0 \%$. Cavallini et al. (2010) modeled sphere-type semivariograms for CP whose parameters $\mathrm{r}^{2}, \mathrm{~A}_{0}$, and SDE were respectively 0.96 , $41.1 \mathrm{~m}$, and $50.0 \%$. Pariz et al. (2011) also registered a spheretype semivariograph model for $\mathrm{GH}$, and respective parameters $\mathrm{r}^{2}, \mathrm{~A}_{0}$, and SDE with $0.61,26.5 \mathrm{~m}$, and $50.3 \%$. However, Montanari et al. (2013b) reported that OM (0$0.10 \mathrm{~m}$ ) provided an exponential-type experimental semivariogram with parameters $0.81\left(\mathrm{r}^{2}\right), 17.7 \mathrm{~m}\left(\mathrm{~A}_{0}\right)$, and 96.7\% (SDE). Similarly, CP provided a Gaussian-type semivariogram with respective rates $0.95\left(\mathrm{r}^{2}\right), 25.6 \mathrm{~m}\left(\mathrm{~A}_{0}\right)$, and $66.5 \%$ (SDE) for the above-mentioned geostatistical parameters. The above revealed that the analysis of the variables provided distinct behaviors in current research.

The crude protein kriging map showed a high direct spatial co-relationship with OM1 and an inverse relationship with GH3 (Figure 2), especially within the central region where the highest $\mathrm{CP}$ rates occurred (7.2 to > $9.8 \%$ ) (Figure $2 \mathrm{~b}$ ). The above coincided spatially with the highest OM1 rates (12.0 to > $16.8 \mathrm{~g} \mathrm{dm}^{-3}$; Figure $2 \mathrm{~d}$ ) and with the lowest $\mathrm{GH} 3$ rates $\left(0.080\right.$ to $0.096 \mathrm{~kg}^{-1}$; Figure $\left.2 \mathrm{e}\right)$. On the other hand, lowest CP rates (4.7 to $7.2 \%$ ) may be observed on the extremities of the maps, whereas OM1 rates were between 7.3 and $12.0 \mathrm{~g} \mathrm{dm}^{-3}$. Similarly, GH3 rates were included between 0.096 and $>0.112 \mathrm{~kg}^{-1}$, with a slight compact in the zones. This fact is common on the margins of the area where trampling of animals and traffic of agricultural machines are highest. It should be emphasized that $\mathrm{OM}$ mineralization is the main $\mathrm{N}$ source since the relationship with $\mathrm{CP}$ is direct and, due to excess of humidity (highest $\mathrm{GH}$ ), $\mathrm{N}$ leaching could occur and, therefore, an inverse response with forage $\mathrm{CP}$ rates.

Since co-kriging between CP and OM1 by the Gaussian model provided a limit of $318.7 \mathrm{~m}$ and high $\mathrm{SDE}$ (99.9\%), it became clear that $72.2 \%$ of $\mathrm{CP}$ spatial variability may be

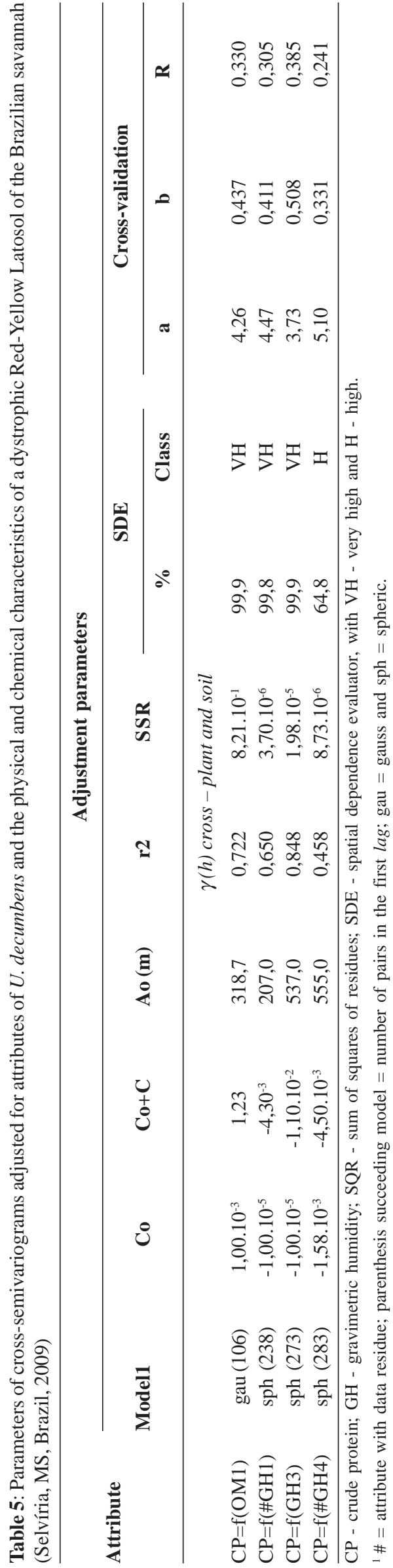

Rev. Ceres, Viçosa, v. 64, n.3, p. 315-326, mai/jun, 2017 

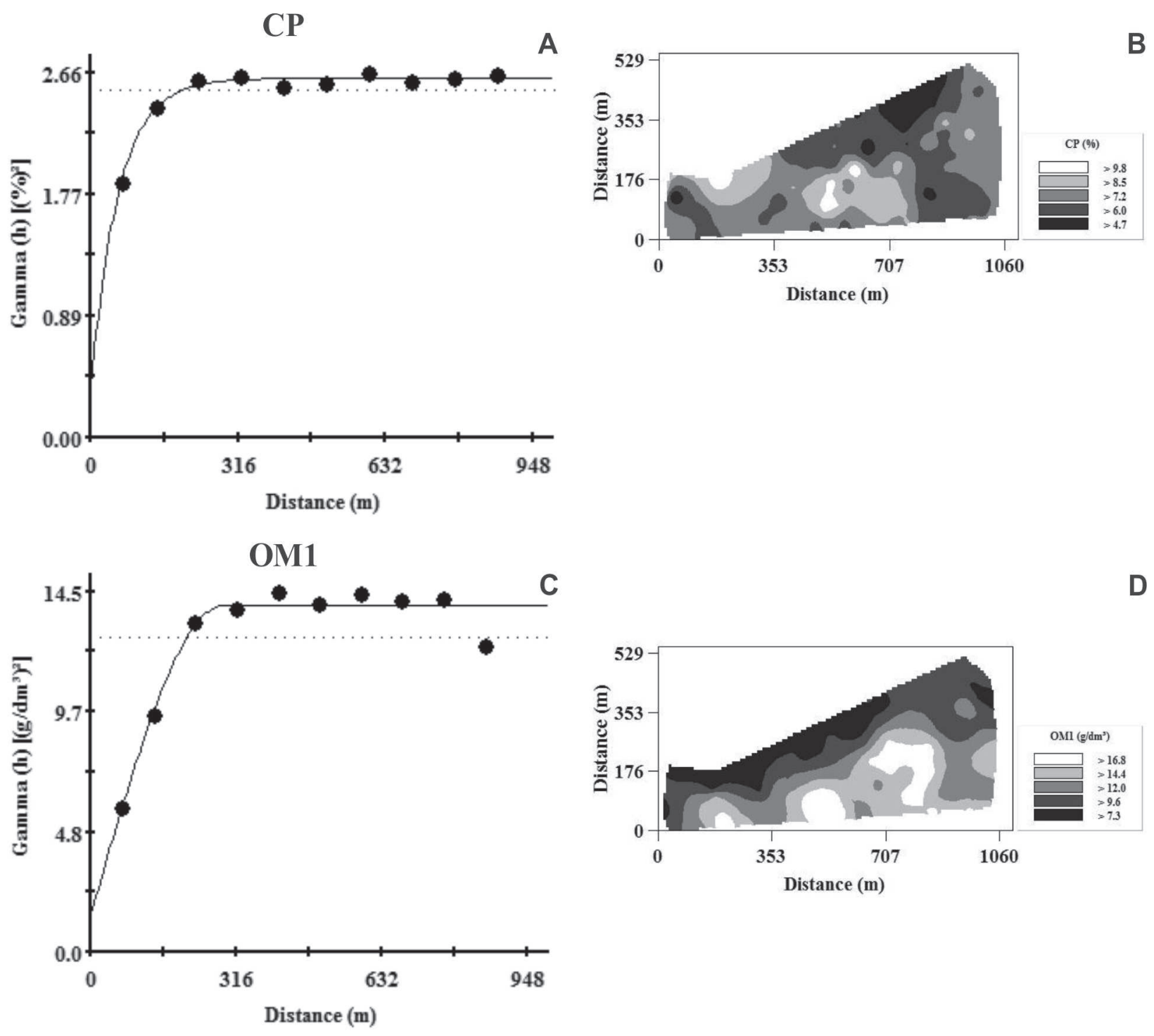

D

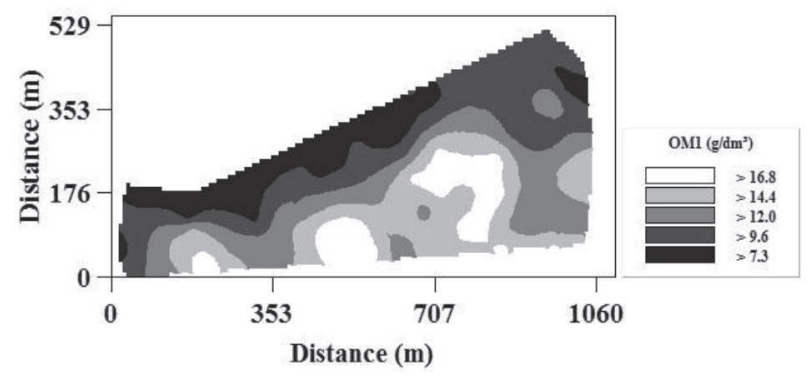

\section{GH3}

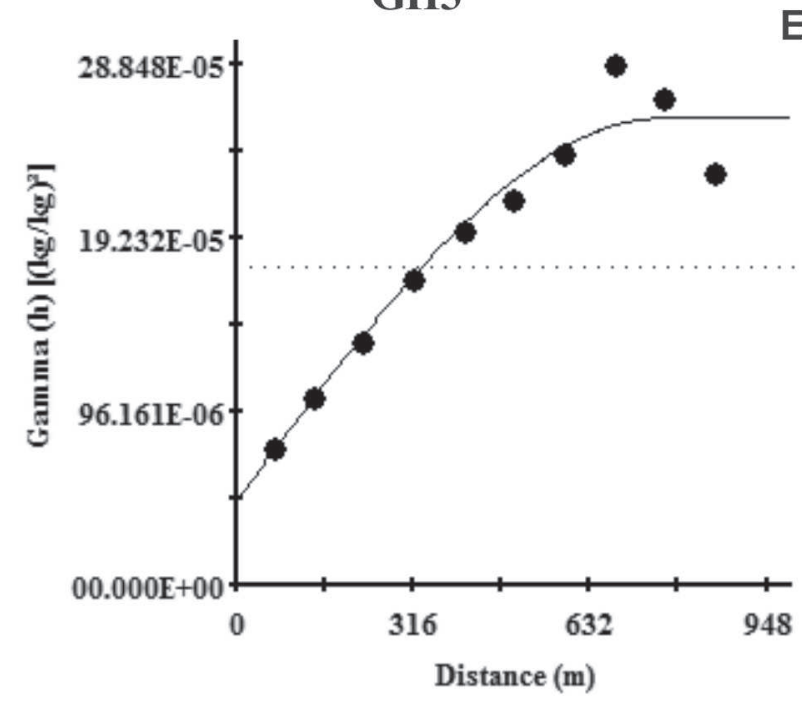

E

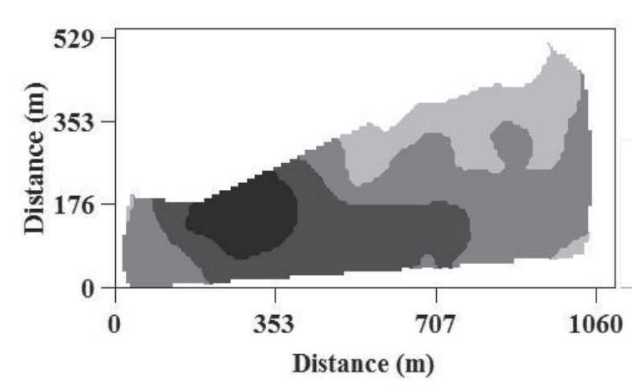

$\mathrm{CP}$ - crude protein; $\mathrm{OM}$ - organic matter; $\mathrm{GH}$ - gravimetric humidity.

Figure 2: Semivariograms and maps of kriging of CP of $U$. decumbens and of OM1 and GH3 of a dystrophic Red-Yellow Latosol of the Brazilian savannah (Selvíria, MS, Brazil, 2009). 
explained by the spatial variability of OM1 (Table 5, Figure 3a,b). In fact, the highest OM1 rates (Figure 3d) provided the highest $\mathrm{CP}$ rates (Figures $2 \mathrm{~b}$ and $3 \mathrm{~b}$ ). The inverse is true. Consequently, from the spatial point of view of the researched area, expected $\mathrm{CP}$ rates in the sites where OM1 varied between 12.0 and $16.8 \mathrm{~g} \mathrm{dm}^{-3}$, lies between 6.9 and $10.4 \%$. On the other hand, in the sites where OM1 lies between 7.3 and $12.0 \mathrm{~g} \mathrm{dm}^{-3}$, CP will be between 3.5 and $6.9 \%$. This reveals the relevance of agricultural practices that aim at raising $\mathrm{OM}$ rates in the soil, since its benefits for the raising of $\mathrm{CP}$ rates for $U$. decumbens becomes evident through improvements in the physical (aggregation) or chemical (fertility) characteristics of the soil (Souza et al., 2004; Boeni et al., 2014; Rocha Junior et al., 2014).

Cross semivariogram (spherical model) and the cokriging map of $\mathrm{CP}$ due to $\mathrm{GH} 3$ proved that spatial variability of $\mathrm{GH} 3$ accounted for $84.8 \%$ of the spatial variability of $\mathrm{CB}$ (Table 5; Figure 3c,d). The sites where the highest GH3 occurred (0.096-0.112 $\mathrm{kg} \mathrm{kg}^{-1}$ ) were precisely and inversely those in which CP provided the lowest rates (4.8 -7.7\%), whereas the sites where the lowest $\mathrm{GH} 3$ rates $(0.080-0.096$ $\mathrm{kg} \mathrm{kg}^{-1}$ ) occurred were the sites in which $\mathrm{CP}$ had the highest rates (7.7-10.7\%). This shows the negative influence of the excessive humidity of the soil on the development of $U$. decumbens in sandy soil and confirms that the species analyzed is not tolerant to environments with high humidity rates, even though it showed low requirements with regard to soil fertility.

Nevertheless, from the point of view of space and soil management, it may be seen that the organic matter and humidity rates of the soil may be perfectly used as indexes of CP rates in the dry matter of $U$. decumbens.

$$
\mathbf{C P}=\mathbf{f}(\mathbf{O M 1})
$$

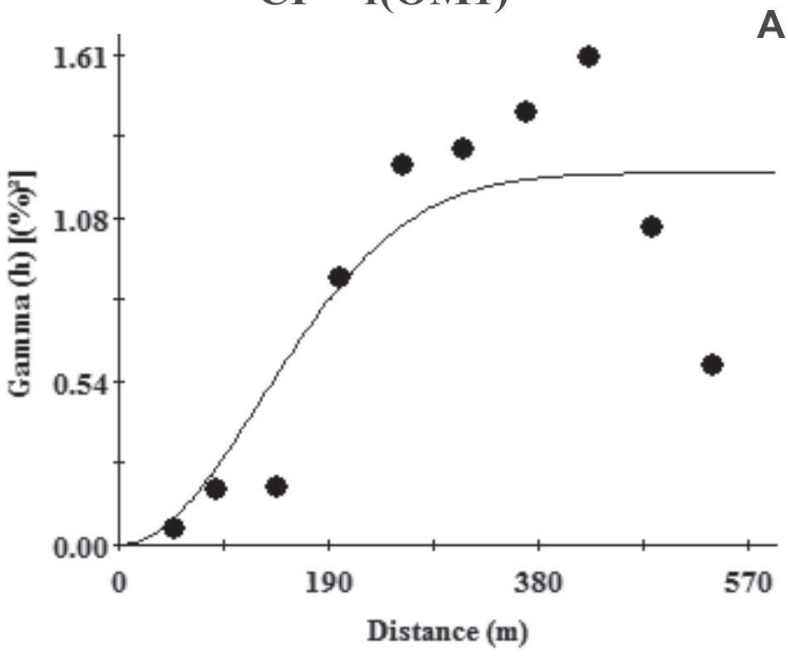

$\mathbf{C P}=\mathbf{f}(\# \mathbf{G H} 3)$

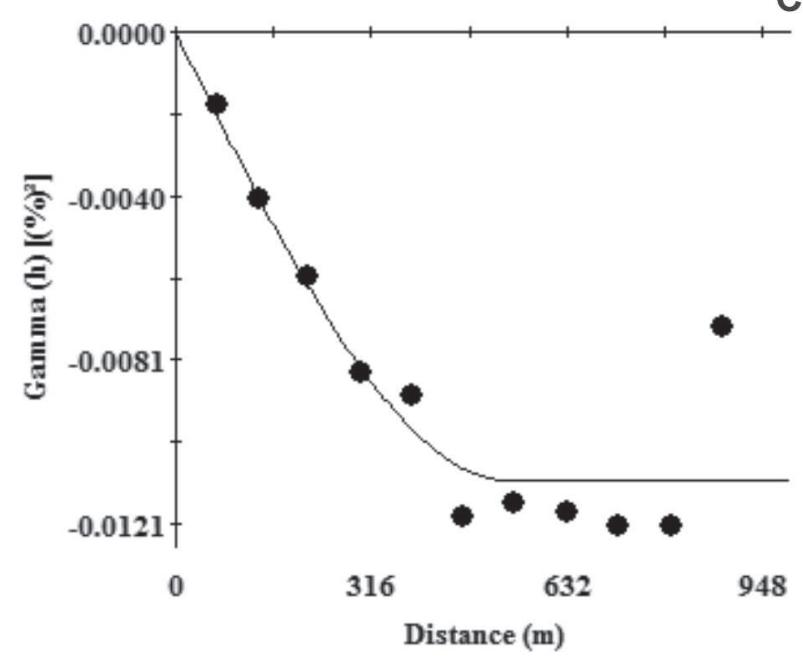

A

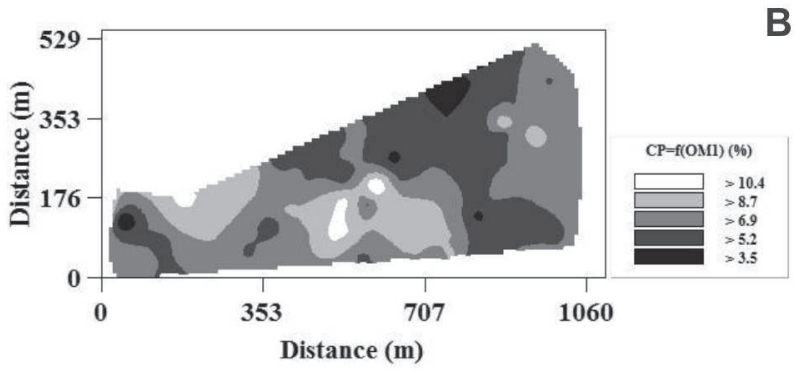

B

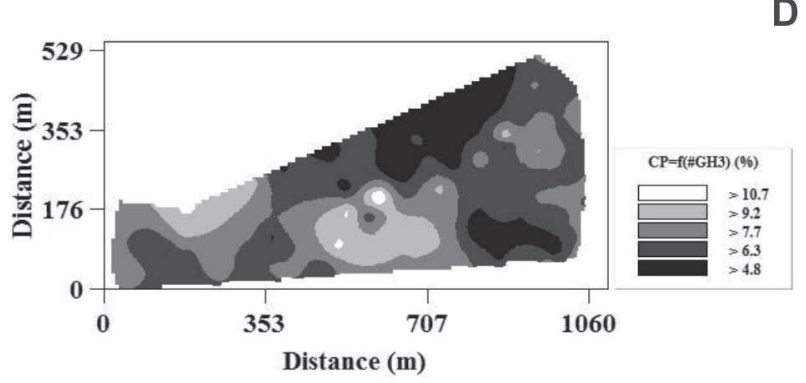

$\mathrm{CP}$ - crude protein; OM - organic matter; GH - gravimetric humidity.

Figure 3: Cross-semivariograms and co-kriging maps of CP of $U$. decumbens as a function of OM1 and GH3 of a dystrophic RedYellow latosol of the Brazilian savannah. Selvíria-MS/Brazil, 2009. 


\section{CONCLUSIONS}

The production of dry matter and the rate of crude protein of Urochloa decumbens may be estimated by regressions through the evaluation of the soil physical attributes such as the mechanical resistance to penetration (crude protein) and gravimetric humidity (dry matter and crude protein).

Organic matter and gravimetric humidity rates of the soil are co-related spatially with the crude protein rates of Urochloa decumbens and reveal the best attributes to estimate and increase the forage crude protein rate as a function of soil management.

\section{REFERENCES}

Arshad MA, Lower B \& Grossman B (1996) Physical tests for monitoring soil quality. In: Doran JW \& Jones AJ (Eds.) Methods for assessing soil quality. Madison, Soil Science Society of America Journal. p.123-141.

Boeni M, Bayer C, Dieckow J, Conceição PC, Dick DP, Knicker H, Salton JC \& Macedo MCM (2014) Organic matter composition in density fractions of Cerrado Ferralsols as revealed by CPMAS ${ }^{13} \mathrm{C}$ NMR: influence of pastureland, cropland and integrated crop-livestock. Agriculture, Ecosystems and Environment, 190:80-86.

Cavallini MC, Andreotti M, Oliveira LL, Pariz CM \& Carvalho MP (2010) Relações entre produtividade de Brachiaria brizantha e atributos físicos de um Latossolo do Cerrado. Revista Brasileira de Ciência do Solo, 34:1007-1015.

Crusciol CAC, Mateus GP, Nascente AS, Martins PO, Borghi E \& Pariz CM (2012) An innovative crop-forage intercrop system: early cycle soybean cultivars and palisadegrass. Agronomy Journal, 104:1085-1095.

Dalchiavon FC, Carvalho MP, Montanari R \& Andreotti M (2013a) Strategy of specification of management areas: rice grain yield as related to soil fertility. Revista Brasileira de Ciência do Solo, $37: 45-54$

Dalchiavon FC \& Carvalho MP (2012) Correlação linear e espacial dos componentes de produção e produtividade da soja. Semina: Ciências Agrárias, 33:541-552.

Dalchiavon FC, Carvalho MP, Montanari R \& Andreotti M (2013b) Sugarcane productivity correlated with physical-chemical attributes to create soil management zone. Revista Ceres, 60:706-714.

Dalchiavon FC, Carvalho MP, Nogueira DC, Romano D, Abrantes FL, Assis JT \& Oliveira MS (2011) Produtividade da soja e resistência mecânica à penetração do solo sob sistema plantio direto no cerrado brasileiro. Pesquisa Agropecuária Tropical, 41:08-19.

Evangelista AR, Abreu JG, Amaral PNC, Pereira RC, Salvador FM \& Santana RAV (2004) Produção de silagem de capim-marandu (Brachiaria brizantha stapf cv. Marandu) com e sem emurchecimento. Ciência e Agrotecnologia, 28:443-449.

Leal ES, Ítavo LCV, Valle CB do, Ítavo CCBF, Dias AM, BarbosaFerreira M, Soares CM, Melo GKA de \& Ferreira VBN (2016) Anti-nutritional potential of protodioscin and kinetics of degradation in Urochloa grasses. Semina: Ciências Agrárias, $37: 2247-2258$.

Leonel FP, Pereira JC, Costa MG, Marco Júnior P, Lara LA \& Queiroz AC (2009) Comportamento produtivo e características nutricionais do capim-braquiária cultivado em consórcio com milho. Revista Brasileira de Zootecnia, 38:177-189.
Lisbôa FM, Donagemma GK, Burak DL, Passos RR \& Mendonça E de S (2016) Indicadores de qualidade de Latossolo relacionados à degradação de pastagens. Pesquisa Agropecuária Brasileira, 51:1184-1193.

Maranhão CMA, Silva CCF, Bonomo P \& Pires AJV (2009) Produção e composição bromatológica de duas cultivares de braquiária adubadas com nitrogênio e sua relação com o índice SPAD. Acta Scientiarum. Animal Sciences, 31:117-122.

Marchão RL, Balbino LC, Silva EM, Santos Junior JDG, Sa MAC, Vilela L \& Becquer T (2007) Qualidade física de um latossolo vermelho sob sistemas de integração lavoura-pecuária no Cerrado. Pesquisa Agropecuária Brasileira, 42:873-882.

Milford R \& Minson DJ (1966) The feeding value of tropical pastures. In: Davies W \& Skidmore CL (Eds.) Tropical pastures. London, Faber and Faber. p.106-1 14.

Montanari R, Carvalho MP, Andreotti M, Dalchiavon FC, Lovera LH \& Honorato MAO (2010) Aspectos da produtividade do feijão correlacionados com atributos físicos do solo sob elevado nível tecnológico de manejo. Revista Brasileira de Ciência do Solo, 34:1811-1822.

Montanari R, Carvalho MP, Silva Junior CA, Corrêa AR, Dalchiavon FC \& González AP (2013c) Relations between the yield of bean (Phaseolus vulgaris L.) and chemical attributes of an Acrustox under no-tillage. Journal of Soil Science and Plant Nutrition, 13:367-379.

Montanari R, Carvalho MP, Teixeira Filho MCM, Dalchiavon FC, Lovera LH \& Honorato MAO (2013b) Produção de matéria seca da braquiária de acordo com os atributos químicos de um Latossolo em Selvíria, Mato Grosso do Sul. Revista Ceres, 60:519527.

Montanari R, Lima ES, Lovera LH, Godoy LTR, Henrique AF \& Dalchiavon FC (2013a) Correlación de la productividad de un forraje con las propiedades físicas de un Ultisol en Aquidauana. Revista Ceres, 60:102-110.

Pariz CM, Carvalho MP, Chioderoli CA, Nakayama FT, Andreotti M \& Montanari R (2011) Spatial variability of forage yield and soil physical attributes of a Brachiaria decumbens pasture in the Brazilian Cerrado. Revista Brasileira de Zootecnia, 40:21112120 .

Pariz CM, Costa C, Crusciol CAC, Meirelles PR de L, Castilhos AM de, Andreotti M, Costa NR \& Martello J (2017) Silage production of corn intercropped with tropical forages in an integrated crop-livestock system with lambs. Pesquisa Agropecuária Brasileira, 52:54-62.

Raij BV, Cantarella H, Quaggio JA \& Furlani AMC (1997) Recomendações de adubação e calagem para o Estado de São Paulo. $2^{\mathrm{a}}$ ed. Campinas, IAC. 285 pages. (Boletim Técnico, 100).

Ribeiro-Júnior NG, Ariano APR \& Silva IV (2017) Death of pastures syndrome: tissue changes in Urochloa hybrida cv. Mulato II and Urochloa brizantha cv. Marandu. Brazilian Journal of Biology, 77:97-107.

Rocha Junior PR da, Donagemma GK, Andrade FV, Passos RR, Balieiro F de C, Mendonça E de S \& Ruiz HA (2014) Can soil organic carbon pools indicate the degradation levels of pastures in the Atlantic Forest biome? Journal of Agricultural Science, 6:84-95.

Serrão EAD \& Simão Neto M (1971) Informações sobre duas espécies de gramíneas forrageiras do gênero Brachiaria na Amazônia: B. decumbens Stapf e B. ruziziensis Germain et Evrard. Belém, Instituto de Pesquisa e Experimentação Agropecuária do Norte. 31 pages.

Silva DJ \& Queiróz AC (2002) Análise de Alimentos: métodos químicos e biológicos. $3^{\mathrm{a}}$ ed. Viçosa, UFV. 235 pages. 
Van Soest PJ (1994) Nutritional ecology of the ruminant. $2^{\mathrm{a}}$ ed. New York, Cornell University. 476 pages.

Souza ZM, Campos MCC, Cavalcante ÍHL, Marques Júnior J, Cesarin LG \& Souza SR (2006) Dependência espacial da resistência do solo à penetração e do teor de água do solo sob cultivo contínuo de cana-de-açúcar. Ciência Rural, 36:128-134.

Souza ZM, Marques Júnior J \& Pereira GT (2004) Variabilidade espacial da estabilidade de agregados e matéria orgânica em solos de relevos diferentes. Pesquisa Agropecuária Brasileira, 39:491-499.
Tormena CA, Silva AP \& Libardi PL (1998) Caracterização do intervalo hídrico ótimo de um Latossolo Roxo sob plantio direto. Revista Brasileira de Ciência do Solo, 22:573-581.

Werner JC, Paulino VT, Cantarella H \& Quaggio

JA (1997) Forrageiras. In: Raij BV, Cantarella H, Quaggio JA \& Furlani AMC (Eds.) Recomendações de calagem e adubação para o Estado

de São Paulo. Campinas, IAC. 285 pages. (Boletim técnico, 100). 